\title{
The influence of IMF By on the nature of the nightside high-latitude ionospheric flow during intervals of positive IMF Bz
}

\author{
A. Grocott, S. V. Badman, S. W. H. Cowley, T. K. Yeoman, and P. J. Cripps \\ Department of Physics \& Astronomy, University of Leicester, Leicester LE1 7RH, UK \\ Received: 10 October 2003 - Revised: 15 January 2004 - Accepted: 23 January 2004 - Published: 8 April 2004
}

\begin{abstract}
This paper further addresses the issue of nightside flow bursts which occur during intervals of northward but strongly $\mathrm{B}_{Y}$-influenced IMF. Recent discussions of such bursts concerned intervals during which the IMF $\mathrm{B}_{Y}$ component was negative. The present study concerns an interval of $\mathrm{B}_{Y}$-positive IMF which occurred on 20 March 2002 (01:0012:00 UT). During the interval $\mathrm{B}_{Y}$ increased steadily from $\sim 2$ to $12 \mathrm{nT}$, whilst the $\mathrm{B}_{Z}$ component decreased steadily from $\sim 10$ to $0 \mathrm{nT}$. There was thus a $\sim 6$-h sub-interval during which the IMF clock angle remained between $30^{\circ}$ and $60^{\circ}$, such that moderate dayside reconnection and open flux production was maintained. It is found that flow bursts of a similar size and speed to those observed under $\mathrm{B}_{Y}$ negative $\left(\sim 1000 \mathrm{~m} \mathrm{~s}^{-1}\right.$, spanning $2-3 \mathrm{~h}$ of MLT in the midnight sector) also occur when $\mathrm{B}_{Y}$ is positive. However, the direction of east-west flow is reversed, indicating that they are driven by processes in the magnetosphere which are directly related to the orientation of the IMF. It is suggested that they are caused by a reconfiguration of an asymmetric tail resulting from prolonged dayside reconnection with a $\mathrm{B}_{Y}$-dominated IMF. This is consistent with previous suggestions that they are associated with convective transport following reconnection in the more distant tail. Analysis of ground magnetic data, auroral images and geosynchronous particle data also show associated features, but indicate that the flow bursts are not directly associated with substorms.
\end{abstract}

Key words. Ionosphere (plasma convection; ionospheremagnetosphere interactions) - Magnetospheric Physics (magnetotail)

\section{Introduction}

The relationship between the nature of the upstream interplanetary magnetic field (IMF) and the concurrent pattern of high-latitude ionospheric plasma convection is reasonably well understood (e.g. Reiff and Burch, 1985; Cowley and

Correspondence to: A. Grocott

(ag27@ion.le.ac.uk)
Lockwood, 1992). In the dayside ionosphere, this relationship is relatively simple, with an immediate response of the ionospheric plasma flow to changes in the IMF readily observable (e.g. Clauer et al., 1984; Etemadi et al., 1988; Todd et al., 1988; Lockwood et al., 1989, 1993; Elphic et al., 1990; Pinnock et al., 1993, 1995; Moen et al., 1995; Provan et al., 1998; Milan et al., 2000). Flows in the nightside ionosphere, however, are more directly controlled by magnetospheric dynamics than by the instantaneous nature of the IMF (e.g. de la Beaujardière et al., 1994; Yeoman and Lühr, 1997; Opgenoorth and Pellinen, 1998; Grocott et al., 2002, 2003, 2004). Although the dynamics of the magnetosphere itself are largely influenced by the IMF (e.g. Dungey, 1961; Farrugia et al., 1993), the magnetotail actively modulates this influence, adding an extra dimension to the complexity of nightside plasma flows. Substorms, for example, are known to influence the nature of nightside convection in a number of ways (Yeoman and Lühr, 1997; Opgenoorth and Pellinen, 1998; Grocott et al., 2002). Recent observations of flows during geomagnetically "quiet" intervals (e.g. Huang et al., 2001; Walker et al., 1998, 2002; Senior et al., 2002; Grocott et al., 2003) have further demonstrated the diversity in nightside convection by revealing a multitude of different flow phenomena associated with various conditions of the IMF.

The particular phenomenon discussed in detail by Senior et al. (2002) and Grocott et al. (2003) were bursts of fast $\left(\sim 1000 \mathrm{~m} \mathrm{~s}^{-1}\right)$ westward auroral zone flow in the nightside ionosphere (see, e.g. Fig. 1). These were observed during extended intervals of modest dayside driving associated with a northward IMF which was dominated by a large negative $\mathrm{B}_{y}$ component. No substorm activity was observed in association with the bursts, which were interpreted as being related to episodic reconnection in the distant magnetotail associated with the closing of open magnetic flux. The present paper continues this investigation by discussing intervals of SuperDARN radar observations of nightside flows during which the IMF was again northward, but now with a significant positive $\mathrm{B}_{y}$ component. The principal aims of this study were to identify firstly, whether similar bursts occur under such conditions and secondly, whether the direction and location 

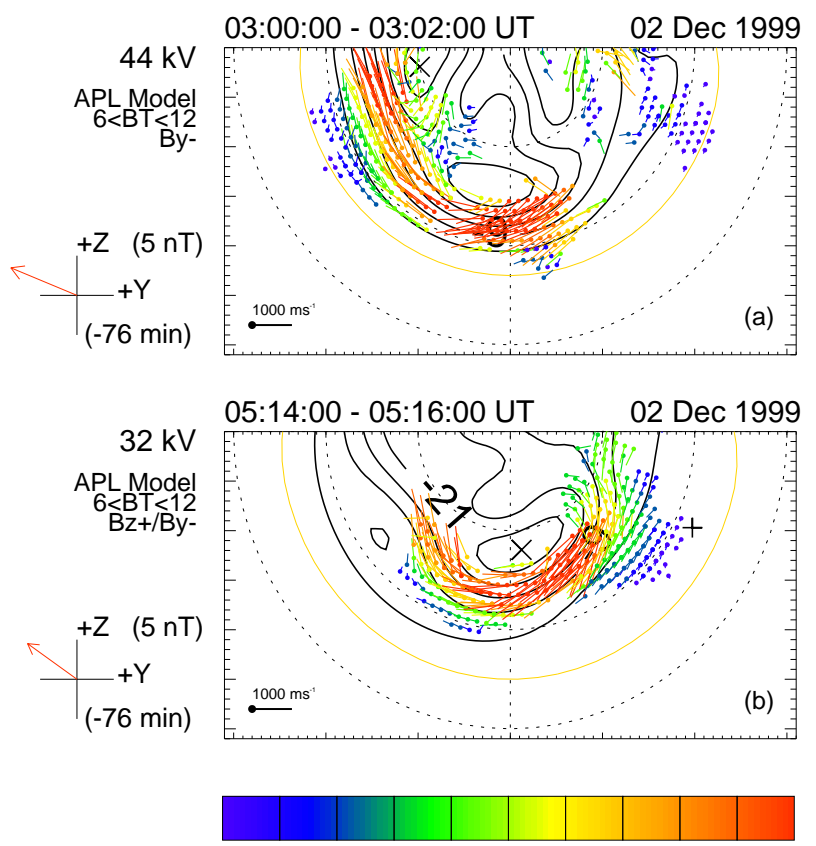

$0 \quad 1002003004005006007008009001000$

Velocity $\left(\mathrm{ms}^{-1}\right)$

Fig. 1. Streamlines and vectors of the nightside ionospheric flow derived from the SuperDARN velocity measurements shown on geomagnetic grids, obtained from the "Map-Potential" algorithm, showing two flow bursts during an interval of northward but $\mathrm{B}_{Y^{-}}$ negative dominated IMF. The exact time interval of each map is indicated in the top left-hand corner, and to the left of each map the total transpolar voltage $V_{P C}$, and the direction and magnitude (in the $Y-Z$ plane) of the lagged IMF are also indicated (adapted from Grocott et al., 2003).

of a burst are determined by the IMF $\mathrm{B}_{y}$ component. Both are found to be the case, with eastward bursts having similar speeds (and similar associated values of transpolar voltage) being observed in the midnight sector auroral zone. Observations from a six hour interval on 20 March 2002 are discussed here in detail (some examples from other intervals are also shown), along with a theory on the origin of the bursts.

\section{Instrumentation}

The main instrumentation employed in this study is that of the Super Dual Auroral Radar Network (SuperDARN) (Greenwald et al., 1995). Data from the nine HF radars which comprise the Northern Hemisphere component of the network have been used to derive large-scale maps of the high-latitude convection using the "Map Potential" model (Ruohoniemi and Baker, 1998). The line-of-sight velocities are mapped onto a polar grid, and used to determine a solution for the electrostatic potential which is expressed in spherical harmonics up to sixth order. The equipotentials of the solution represent the plasma streamlines of the

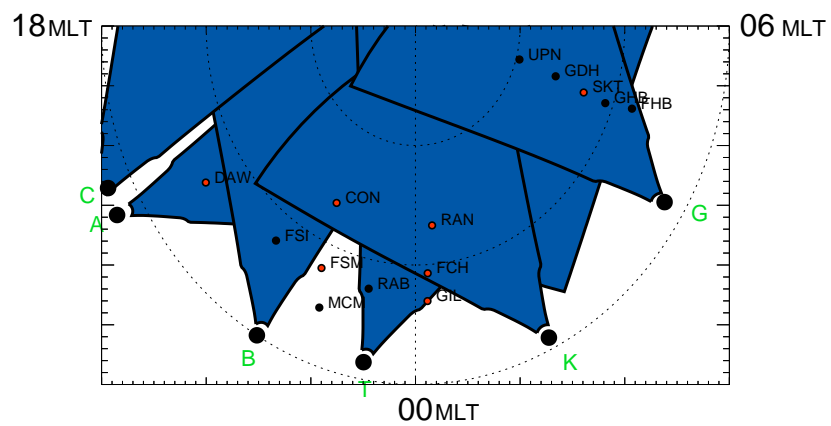

Fig. 2. Fields-of-view of the Northern Hemisphere SuperDARN radars at 07:00 UT, the centre time of the main interval considered in this paper. These are plotted on a geomagnetic grid with the pole at the top and dusk to the left, down to $60^{\circ}$. Also shown are ground-based magnetometer locations, with red dots indicating stations whose data has been explicitly shown in this paper.

modelled convection pattern. Information from the statistical model of Ruohoniemi and Greenwald (1996), parameterised by concurrent IMF conditions, is used to stabilise the solution where no data are available. A Heppner-Maynard boundary (Heppner and Maynard, 1987), determined from the line-of-sight velocity data, is also used to constrain the convection pattern at lower latitudes. The flow vectors which will be shown superposed on the electric equipotentials are derived using the SuperDARN line-of-sight velocity measurements with the transverse velocity component provided by the spherical harmonic fits.

The fields-of-view of those SuperDARN radars which spanned the nightside ionosphere at 07:00 UT (the central time of the main interval studied) are shown in Fig. 2. These are presented in Altitude Adjusted Corrected Geomagnetic (AACGM) coordinates, a development of the PACE system discussed by Baker and Wing (1989). Midnight magnetic local time (MLT) is at the bottom and dusk is to the left. The locations and identifier codes of a set of magnetometers used are also displayed on Fig. 2. Data have been inspected from magnetograms of these two arrays which move through the midnight sector during the study interval. These are the Canadian CANOPUS array (Grant et al., 1992) and the Greenland magnetometer chain (Friis-Christensen et al., 1985). Data from selected stations (denoted by the red-filled circles) will be presented in $H, D$, and $Z$ coordinates, where $H$ is local magnetic north, $D$ is local magnetic east, and $Z$ is vertically down. The locations and codes of this subset of stations will also be indicated on the flow maps.

IMF conditions for each study interval were measured by the MAG instrument (Smith et al., 1999) on board the ACE spacecraft (Stone et al., 1998). During the 20 March interval ACE was located upstream at GSM coordinates (X, Y, $\mathrm{Z})=(222,-14,-15) \mathrm{R}_{E}$ (with negligible movement over the interval). Solar wind data obtained by the SWEPAM instrument (McComas et al., 1998) were also used to estimate the propagation delay of field changes from ACE to the dayside ionosphere using the algorithm of Khan and Cowley (1999). 
This was found to be $71 \pm 7$ min for the 20 March interval and has been used to lag the ACE IMF data displayed here. Similar delay times were found for the other intervals studied and have been used to lag the relevant IMF data as appropriate.

\section{Observations}

\subsection{Upstream interplanetary conditions}

Figure 3 shows the lagged ACE interplanetary magnetic field data in GSM coordinates for the interval 01:00-12:00 UT on 20 March 2002, during which the IMF had both positive $\mathrm{B}_{Z}$ and $\mathrm{B}_{Y}$ components. The clock angle increased steadily from less than $10^{\circ}$ (almost purely northward) at 01:00 UT, to $\sim 90^{\circ}$ (purely duskward) at 12:00 UT. This corresponds to a decrease in $\mathrm{B}_{Z}$ over the interval from $\sim 10 \mathrm{nT}$ at 01:00 UT, to $\sim$ zero by 12:00 UT, and an increase in $\mathrm{B}_{Y}$ which became dominant as it climbed from $\sim 2 \mathrm{nT}$ at 01:00 UT to $\sim 12 \mathrm{nT}$ by 12:00 UT. $\mathrm{B}_{X}$ remained steady at around $6 \mathrm{nT}$ and the magnitude of the IMF remained strong between 13 and $16 \mathrm{nT}$ throughout the interval. The vertical dashed lines delimit the interval of SuperDARN data which has been studied (04:0010:00 UT), during which the clock angle was at intermediate angles of $30^{\circ}$ to $60^{\circ}$ (such that, according to, for example, Sandholt et al. (1998a, b) a modest level of dayside reconnection should prevail). This is some $3 \mathrm{~h}$ after the IMF initially acquired its $\mathrm{B}_{Y}$ and $\mathrm{B}_{Z}$ positive orientation, however, such that the nightside flows should not have been influenced by any prior magnetospheric activity which might be associated with more typically "active" IMF conditions.

\subsection{SuperDARN observations of ionospheric flow}

As mentioned above, SuperDARN data for this interval have been studied between 04:00 and 10:00 UT, corresponding to the interval during which the IMF clock angle was between $30^{\circ}$ and $60^{\circ}$. This also corresponds to the interval during which the coverage of SuperDARN data was sufficient to reasonably dominate the fitting of the ionospheric electric potential in the Map Potential model and produce reliable convection maps. Figure 4 shows two such maps from early on in the interval when the data spanned the dusk, dawn and nightside sectors sufficiently to produce reasonably complete pictures of the ionospheric flow. The bold numbers on the maps indicate the ionospheric electric potentials (discussed in Sect. 2) which, for the Northern Hemisphere, are negative at dusk (clockwise flow) and positive at dawn (anti-clockwise flow). The difference between the peaks of these positive and negative potentials thus gives a useful indication of the magnitude of the convection over the polar cap, referred to as the transpolar voltage.

The two maps shown are at (a) 05:30 and (b) 06:30 UT, respectively, and show the calculated transpolar voltage, the APL statistical convection model used, and an icon representing the IMF strength and orientation in the Y-Z plane. These two maps are representative of the overall nature of the flow during the interval, which is dominated by a large

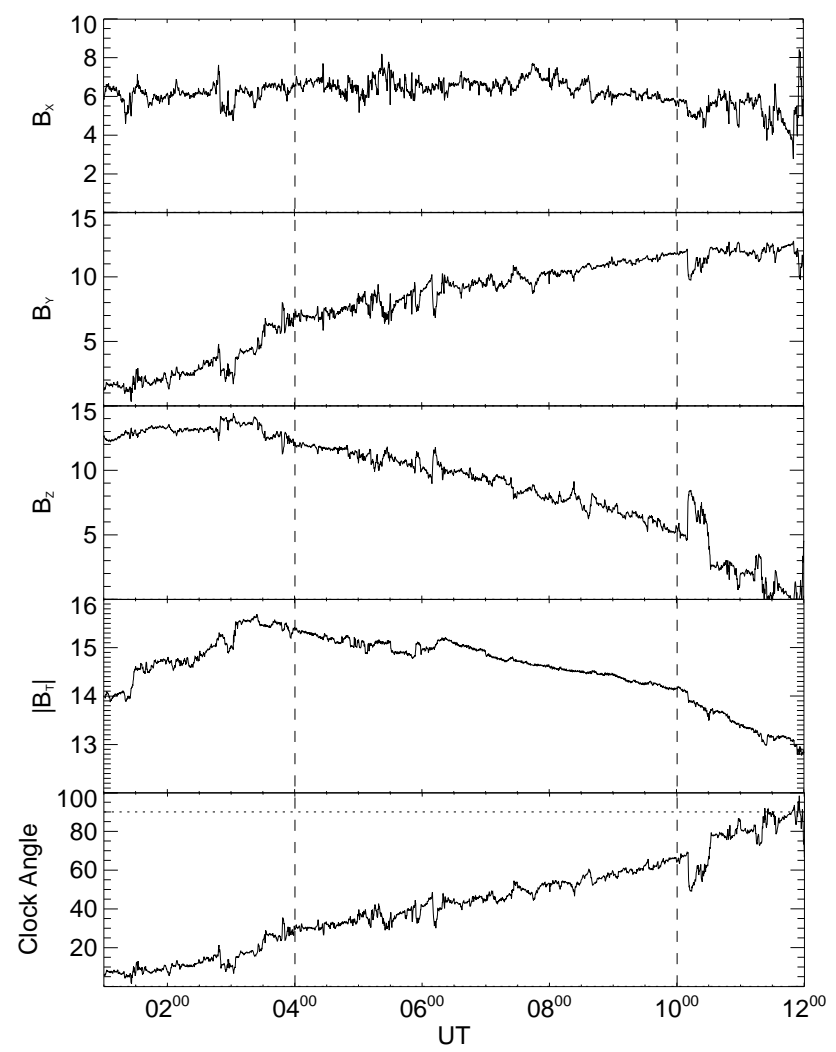

Fig. 3. Upstream interplanetary observations from the ACE spacecraft for 01:00-12:00 UT on 20 March 2002, lagged by 71 min to account for the propagation delay to the ionosphere. The top three panels show IMF data in GSM co-ordinates, and the bottom two panels show the field magnitude and clock angle. The clock angle is defined with respect to north, such that $0^{\circ}$ corresponds to a transverse field purely in the $+z$ direction (northward), $\pm 90^{\circ}$ to $\pm y$ (respectively) and $\pm 180^{\circ}$ to $-z$ (southward).

crescent-shaped dawn cell extending from pre-midnight to post-dawn. Owing to the intermediate nature of the IMF clock angle during this interval, one might expect to observe both Dungey-cycle and lobe convection cells (Crooker et al., 1998; Sandholt et al., 1998a, b, 2001). However, this is not well addressed by the data employed (due to lack of complete coverage) and since the presence of lobe cells is not germane to the subject of this study, they are not considered any further. What is clearly evidenced by the data is the continued excitation of Dungey-cycle twin-cell flow. The antisunward flow has a westward component over the polar cap, opposite to that reported by Grocott et al. (2003) for negative $\mathrm{B}_{Y}$, and is exactly that expected for Dungey-cycle flow in the presence of positive IMF $\mathrm{B}_{Y}$ (Jørgensen et al., 1972; Reiff and Burch, 1985). The flow reversal boundary was observed at a magnetic latitude of between $70^{\circ}$ and $75^{\circ}$ throughout the interval, although there was no trend apparent in any variation. This implies a relatively constant size of polar cap and therefore an approximate balance between dayside and nightside reconnection over the interval. Modest velocities of a few $\sim 100 \mathrm{~m} \mathrm{~s}^{-1}$ persisted throughout the interval, with an average transpolar voltage of $\sim 30 \mathrm{kV}$. 

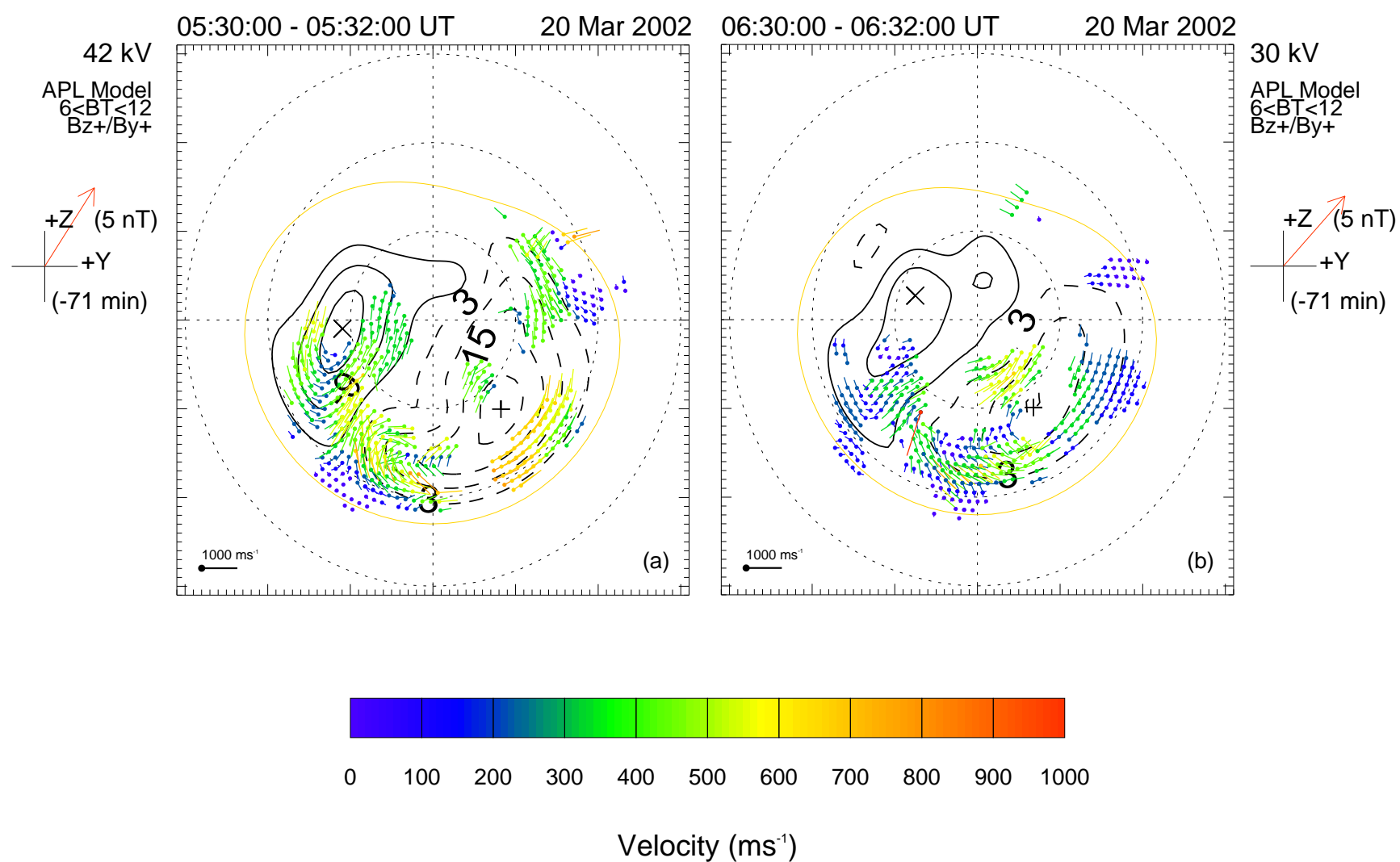

Fig. 4. Flow maps illustrating the overall nature of ionospheric convection during the main interval discussed in this paper. Two maps are shown, the exact time of each being indicated in the top left-hand corner. The total transpolar voltage $V_{P C}$, and the direction and magnitude (in the $Y-Z$ plane) of the lagged IMF are also indicated, as in Fig. 1.

Inspection of the flow maps for the entire interval reveals that convection did not persist at these average levels but, as was found by Grocott et al. (2003), was instead interspersed with bursts of much faster flow $\left(>1000 \mathrm{~m} \mathrm{~s}^{-1}\right)$ in the midnight sector, each lasting of the order of $10 \mathrm{~min}$. These bursts (eight of which are illustrated in Fig. 5, panels (ah)) recurred on a time scale of 30-60 min and (usually) involved an enhancement of the transpolar voltage by about $5-10 \mathrm{kV}$ above the background level. The peak flows during each burst are shown on maps of the nightside ionosphere which are otherwise presented in the same style as those in Fig. 4, except for the filled black circles which indicate the locations of key magnetometers, data from which are discussed below. The geometry of each burst shown in Fig. 5 is essentially the same, involving flows which emanate from the polar cap in the pre-midnight sector and then reverse in sense, travelling eastwards back towards the dayside via midnight. Whilst therefore similar to the bursts reported by Grocott et al. (2003), their direction is clearly opposite, apparently determined by the sense of IMF $\mathrm{B}_{Y}$. This is further evidenced by Fig. 6, which shows four bursts from two additional intervals of $\mathrm{B}_{Z}$-positive, $\mathrm{B}_{Y}$-positive on 30 May 2001 (panels (a-b)) and 23 September 2002 (panels (c-d)). These four bursts (and indeed, bursts from a number of other intervals studied) are similar in nature to those from the main interval discussed here, which would therefore appear to be common to the prevailing interplanetary conditions.

\subsection{Ground magnetometer data}

A representative subset of the magnetometer data inspected for the 20 March interval is shown in Fig. 7, corresponding to the magnetometers indicated in Fig. 5 and to the red-filled circles in Fig. 2. The vertical dashed lines indicate the times of the peaks in flow burst activity shown in Fig. 5. The top two traces, from the DAW and FSM magnetometers, show negligible perturbations throughout the interval. As is evident from Fig. 5, these stations were located consistently equatorward of the main flow enhancements which occurred. The first, and most significant signature, was at $\sim 04: 15 \mathrm{UT}$, corresponding to the onset of the first flow burst (the peak of which is shown in Fig. 5 at 04:38 UT). This signature is largest in the RAN magnetometer data, which shows a substorm-like negative bay of $\sim 120 \mathrm{nT}$. This was also the disturbance with the largest spatial extent during the interval, having been observed by CON and FCH. Many of the subsequent bursts were also accompanied by more localised magnetic bay-type disturbances of amplitude up to $80 \mathrm{nT}$. SKT of the Greenland chain, being the most eastern station shown, only saw a perturbation for the first couple of hours of the interval before moving out of the enhanced flow region after 


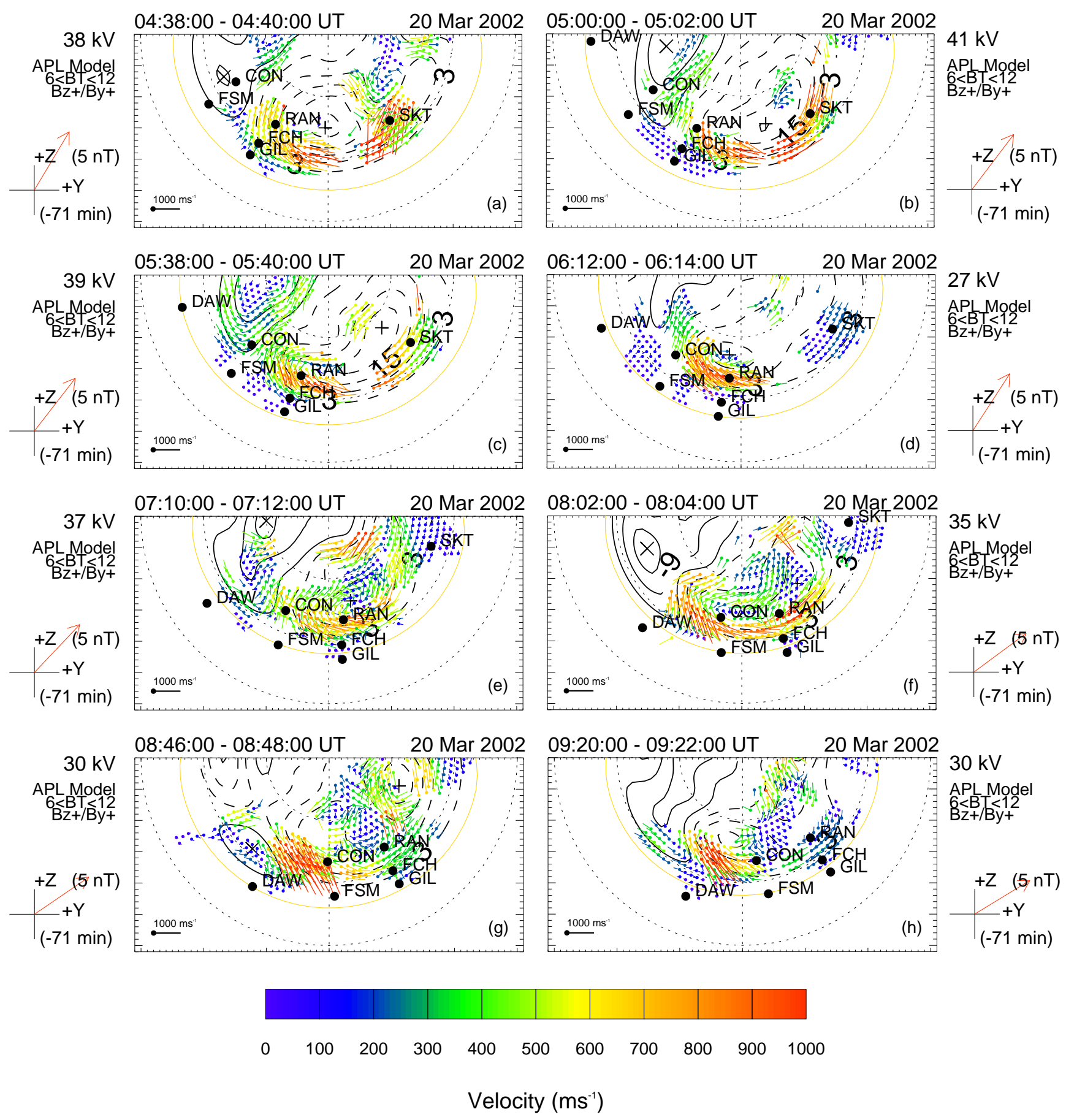

Fig. 5. Flow maps illustrating the flow "bursts" from the main interval are shown in the same format as Fig. 1. Eight maps are shown with the exact time of each 2-min map again indicated in the top left-hand corner. Also indicated on the maps by the black circles are the locations of the magnetometer stations colour-coded red in Fig. 1. 

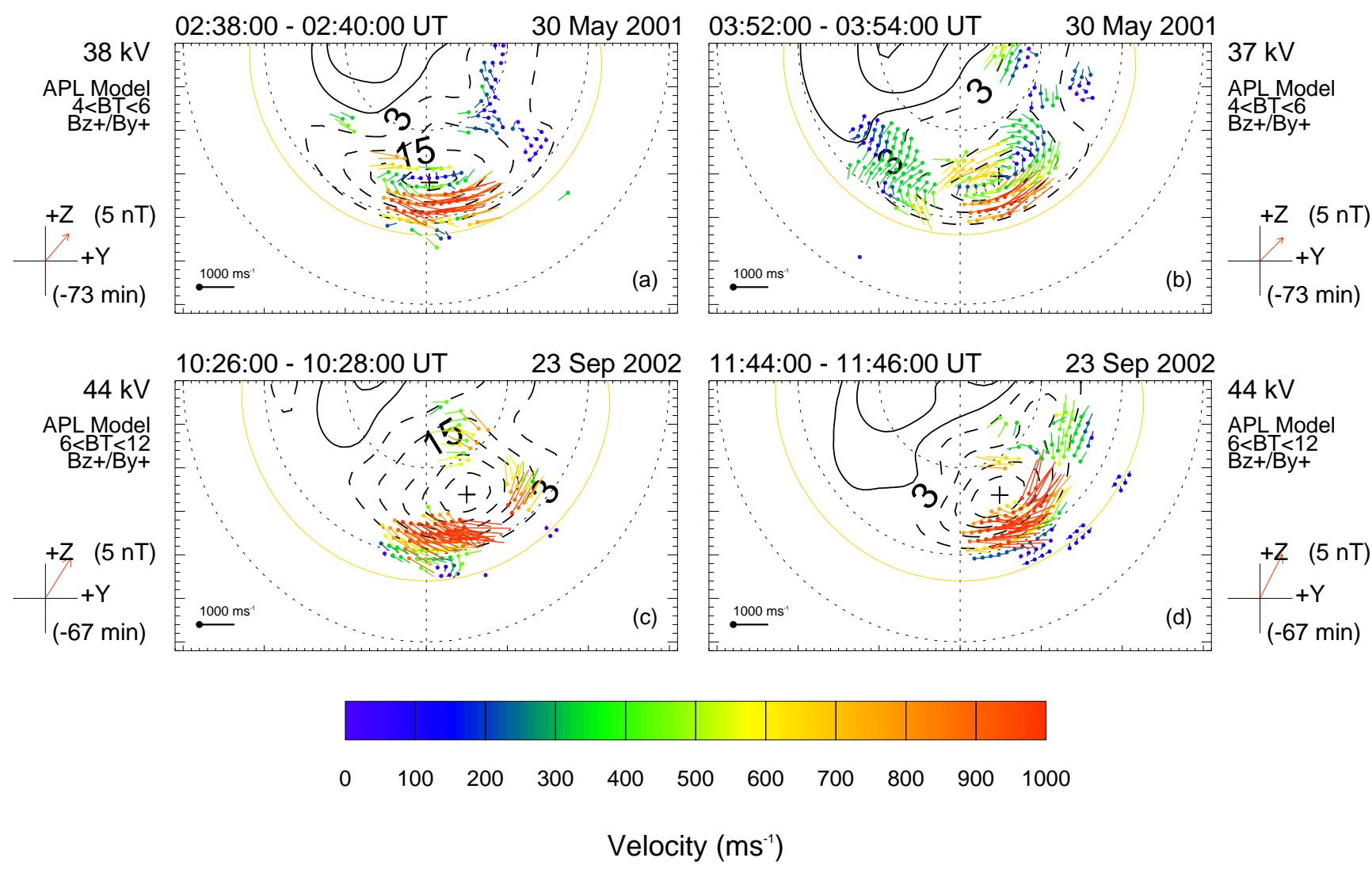

Fig. 6. Flow maps illustrating the flow "bursts" from two additional intervals are shown in the same format as Fig. 1.

about 06:00 UT. The most eastern of the CANOPUS stations (such as GIL, illustrated) also show a noticeable impulsive increase in Pi2 amplitude at around 04:15 UT. This enhanced Pi2-band activity then remained for the duration of the interval. Other magnetometers in the chain also recorded the Pi2 activity but without observing a significant perturbation in the unfiltered H-component.

It is worth noting that images from the SIE instrument on board the IMAGE spacecraft (Mende et al., 2000a, b) (not shown) indicate a modest brightening of the Northern Hemisphere auroral oval during the main interval but offer no evidence of substorm activity. LANL geosynchronous particle data (Belian et al., 1992) (also not shown) provide evidence of a slight enhancement in energetic electron flux over the whole interval, but not of impulsive injection signatures which would also be indicative of substorm activity.

\section{Discussion}

It is clear, both from the observations discussed above and from the results of the previous studies mentioned in the Introduction, that the nightside ionosphere and geomagnetic tail during intervals of northward IMF are often anything but quiescent. However, with such a wealth of phenomena reported and the relationships between many of them as yet unclarified, no overall picture has emerged of the behaviour of the tail and conjugate ionosphere under these conditions. The data presented above clearly demonstrate that the nightside high-latitude ionospheric flows reported by Grocott et al. (2003) for northward IMF with $\mathrm{B}_{Y}$-negative also occur during corresponding intervals with $\mathrm{B}_{Y}$-positive. The data also show that the direction of the flows is governed by the orientation of $\mathrm{B}_{Y}$, implying that the tail dynamics responsible for driving them are also directly related to the nature of the IMF.

\subsection{Origin of the flow bursts}

A possible mechanism by which the flow bursts are produced is illustrated schematically in Fig. 8, which shows a view looking down on the northern polar ionosphere, with noon to the top and dusk to the left. The open-closed field line boundary is shown as a dashed line, with the $\mathrm{B}_{Y}$-positive Dungeycycle twin convection vortices shown as the solid arrowed curves, black for the Northern Hemisphere and grey for the expected simultaneous flow in the Southern Hemisphere. As the diagram is schematic, it may not reflect the details on the less-well observed dayside. Nonetheless, dayside reconnection between terrestrial field lines and the $\mathrm{B}_{Y}$-positive IMF creates open flux tubes which are pulled towards dawn in the Northern Hemisphere and dusk in the Southern Hemisphere. As these flux tubes are dragged over the polar caps they produce an asymmetry in the tail in which the lobes are twisted 


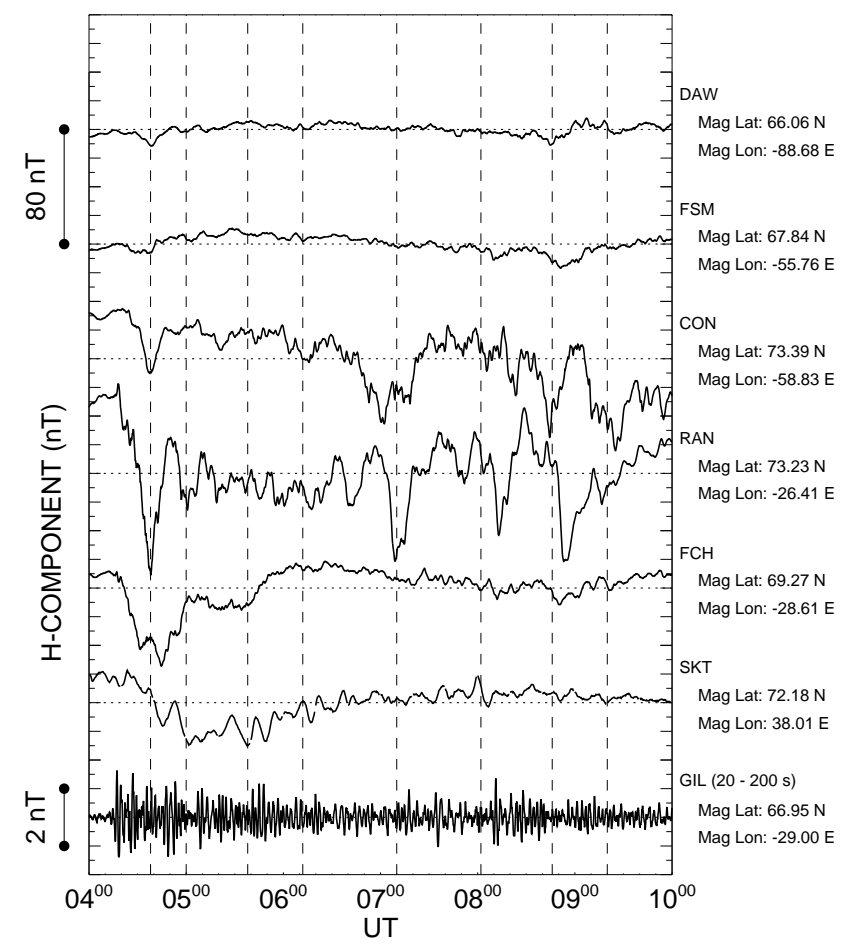

Fig. 7. $H$-component magnetic field measurements from the red colour-coded array of stations in Fig. 1, for 04:00-10:00 UT on 20 March 2002. The upper 6 curves show unfiltered $H$-component magnetic field measurements and the bottom curve shows filtered (20-200 s) data. The vertical dashed lines correspond to the times of the bursts shown in Fig. 5. The station codes and locations in magnetic longitude and latitude are also shown.

in association with the appearance of a perturbation field in the tail which has the same sense as the IMF $\mathrm{B}_{Y}$ (Fairfield, 1979; Cowley, 1981; Nishida et al., 1998). A schematic representation of tail field lines is given by the numbered arrowed lines in Fig. 8. 1 (1') is a newly reconnected field line from the Northern (Southern) Hemisphere. Owing to the $\mathrm{B}_{Y}$-asymmetry, the northern footprint of the field line is displaced considerably westward of the southern footprint, and has a much longer path in the ionosphere back to the dayside. As the field line untwists itself (through positions 2 and 3) its Northern Hemisphere footprint moves faster to catch up with its southern counterpart, which results in a burst of flow across the midnight sector of the nightside ionosphere (thick black arrowed curve). An opposite tail lobe asymmetry and hence opposite direction of flow burst would therefore be expected for the opposite sense of IMF $\mathrm{B}_{Y}$.

\subsection{Comparison with $\mathrm{B}_{Y}$-negative}

The schematic representation of flow bursts presented above explains the fundamental difference between the bursts discussed in this paper and those reported by Grocott et al. (2003), in that the direction of the flow is determined by the prevailing sense of IMF $\mathrm{B}_{Y}$. However, there are other differences between the two phenomena which are not so eas-

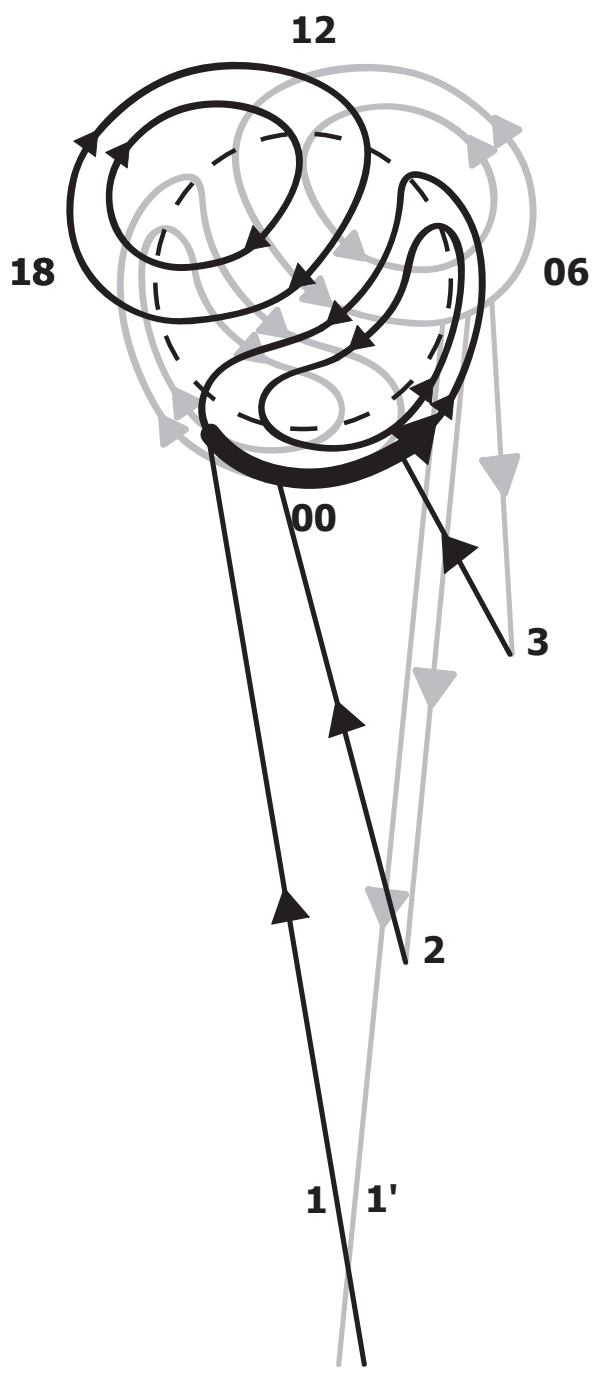

Fig. 8. Schematic of a possible mechanism by which the flow bursts are produced showing a view looking down on the northern polar ionosphere with noon to the top and dusk to the left. The openclosed field line boundary is shown as a dashed line, with the $\mathrm{B}_{Y^{-}}$ positive Dungey-cycle twin convection vortices shown as the solid arrowed curves, black for the Northern Hemisphere and grey for the simultaneous flow in the Southern Hemisphere. Tail field lines are represented by the numbered arrowed lines where $1\left(1^{\prime}\right)$ is a newlyreconnected field line from the Northern (Southern) Hemisphere, and 2 and 3 are the same field line at later times.

ily explained, the most obvious being the existence of negative substorm-like bays in the ground magnetometer data. This, along with the pronounced Pi2 signatures observed in association with the bursts, as well as the slight enhancement in energetic electron flux observed at geosynchronous orbit, might lead one to suspect that these phenomena are in fact small-amplitude substorms. Only by comparing these bursts to those in the $\mathrm{B}_{Y}$-negative scenario does it become clear that this is not the case. The $\mathrm{B}_{Y}$-negative bursts were accompanied by northward deflections in the ground magnetic field and Grocott et al. (2003) showed these to be in regions of low conductivity where the flow velocity was high. 
Indeed, it was also found in the present study (as discussed in Sect. 3.3, above) that only those magnetometers located inside the high speed flow region measured significant magnetic perturbations. This, along with the lack of any significant substorm-like enhancement in auroral emissions, suggests that the magnetic signatures associated with the flow bursts are driven primarily by changes in the electric field, rather than by enhanced conductivities. During substorm expansions it is always an enhanced westward electrojet which is observed, irrespective of the sense of IMF $\mathrm{B}_{Y}$, and this is usually in a region of conductivity-induced flow suppression (e.g. Kirkwood et al., 1988; Morelli et al., 1995; Yeoman et al., 2000). It is likely, therefore, that the flow bursts observed for the $\mathrm{B}_{Y}$-positive case are in effect the same phenomenon as the $\mathrm{B}_{Y}$-negative bursts and resemble substorms more simply because they are associated with a current system which has the same orientation. They are, however, an important part of the "substorm" story in the larger sense of presumably relating to impulsive tail reconnection. A more comprehensive study of a larger number of both $\mathrm{B}_{Y}$-positive and negative intervals should more fully elucidate their relationship both to substorms and to the nature of the upstream IMF.

\section{Summary}

This paper has further addressed the issue of nightside flow bursts which occur during intervals of northward but strongly $\mathrm{B}_{Y}$-influenced IMF, discussed previously by Senior et al. (2002) and Grocott et al. (2003). The main interval studied here (01:00-12:00 UT on 20 March 2002) is one in which the IMF had a significant positive $\mathrm{B}_{Y}$ component, in contrast to the $\mathrm{B}_{Y}$-negative intervals mentioned above. It is found that flow bursts of a similar size and speed to those observed when $B_{Y}$ is negative $\left(\sim 1000 \mathrm{~m} \mathrm{~s}^{-1}\right.$, spanning $2-3 \mathrm{~h}$ of MLT) also occur when $\mathrm{B}_{Y}$ is positive. However, their direction is reversed, indicating that they are driven by processes in the magnetosphere which are directly related to the orientation of the IMF. It is suggested that they could be caused by a reconfiguration of an asymmetric tail, resulting from prolonged dayside reconnection with a $\mathrm{B}_{Y}$-dominated IMF. This is consistent with previous suggestions that they are associated with convective transport following reconnection in the tail. Analysis of ground magnetic data, auroral images and geosynchronous particle data also show associated features, but indicate that the flow bursts are not directly associated with substorms. Ongoing work will address the range of IMF clock angles over which they occur, and further elucidate the relationship between the nature of the IMF and consequent magnetospheric dynamics.

Acknowledgements. We would like to thank the PIs of the SuperDARN radars for provision of the radar data employed in this study. The data employed were from radars funded by the research funding agencies of Canada, France, Japan, the UK, and USA. We would also like to thank Dr Mike Ruohoniemi of the Johns Hopkins University Applied Physics Laboratory for provision of the "Map-
Potential" algorithm software. For the ground magnetometer data, we thank the Canadian Space Agency who constructed and maintain the CANOPUS instrument array, and Jürgen Watermann and the Danish Meteorological Institute for the Greenland data. For provision of ACE magnetometer data we thank Norman Ness and Charles Smith of the Bartol Research Institute. AG was supported during this study by PPARC grant PPA/G/O/2001/00014, and SWHC by PPARC Senior Fellowship PPA/N/S/2000/00197. SuperDARN operations at the University of Leicester are supported by PPARC grant PPA/R/R/1997/00256.

Topical editor T. Pulkkinen thanks T. S. Jorgensen and D. Fairfield for their help in evaluating this paper.

\section{References}

Baker, K. B. and Wing, S.: A new magnetic coordinate system for conjugate studies at high latitudes, J. Geophys. Res., 94, 91399143, 1989.

Belian, R. D., Gisler, G. R., Cayton, T., and Christensen, R.: High$\mathrm{Z}$ energetic particles at geostationary orbit during the great solar proton event series of October 1989, J. Geophys. Res., 97, 16897-16906, 1992.

Clauer, C. R., Banks, P. M., Smith, A. Q., Jorgensen, T. S., FriisChristensen, E., Vennerstrom, S., Wickwar, V. B., Kelly, J. D., and Doupnik, J.: Observation of interplanetary magnetic-field and of ionospheric plasma convection in the vicinity of the dayside polar cleft, Geophys. Res. Lett., 11, 891-894, 1984.

Cowley, S. W. H.: Magnetospheric asymmetries associated with the Y-component of the IMF, Planet. Space Sci., 29, 79-96, 1981.

Cowley, S. W. H. and Lockwood, M.: Excitation and decay of solar wind-driven flows in the magnetosphere-ionosphere system, Ann. Geophysicae, 10, 103-115, 1992.

Crooker, N. U., Lyon, J. G., and Fedder, J. A.: MHD model merging with IMF $\mathrm{B}_{y}$ : Lobe cells, sunward polar cap convection and overdraped lobes, J. Geophys. Res., 103, 9143-9151, 1998.

De la Beaujardière, O., Lyons, L. R., Ruohoniemi, J. M., FriisChristensen, E., Danielsen, C., Rich, F. J., and Newell, P. T.: Quiet-time intensifications along the poleward boundary near midnight, J. Geophys. Res., 99, 287-298, 1994.

Dungey, J. W.: Interplanetary magnetic field and the auroroal zones, Phys. Rev. Lett., 6, 47-48, 1961.

Elphic, R. C., Lockwood, M., Cowley, S. W. H., and Sandholt, P. E.: Flux transfer events at the magnetopause and in the ionosphere, Geophys. Res. Lett., 17, 2241-2244, 1990.

Etemadi, A., Cowley, S. W. H., Lockwood, M., Bromage, B. J. I., Willis, D. M., and Lühr, H.: The dependence of high-latitude dayside ionospheric flows on the north-south component of the IMF: a high-time resolution correlation analysis using EISCAT "Polar" and AMPTE UKS and IRM data, Planet. Space Sci., 36, 471, 1988.

Fairfield, D. H.: On the average configuration of the geomagnetic tail, J. Geophys. Res., 84, 1950-1958, 1979.

Farrugia, C. J., Freeman, M. P., Burlaga, L. F., Lepping, R. P., and Takahashi, K.: The Earth's magnetosphere under continued forcing: Substorm activity during the passage of an interplanetary magnetic cloud, J. Geophys. Res., 98, 7657-7671, 1993.

Friis-Christensen, E., Kamide, Y., Richmond, A. D., and Matsushita, S.: Interplanetary magnetic field control of high-latitude electric fields and currents determined from Greenland magnetometer data, J. Geophys. Res., 90, 1325-1338, 1985. 
Grant, I. F., McDiarmid, D. R., and McNamara, A. G.: A class of high-m pulsations and its auroral radar signature, J. Geophys. Res., 97, 8439-8451, 1992.

Greenwald, R. A., Baker, K. B., Dudeney, J. R., Pinnock, M., Jones, T. B., Thomas, E. C., Villain, J.-P., Cerisier, J.-C., Senior, C., Hanuise, C., Hunsucker, R. D., Sofko, G., Koehler, J., Nielsen, E., Pellinen, R., Walker, A. D. M., Sato, N., and Yamagishi, H.: DARN/SuperDARN: A global view of the dynamics of highlatitude convection, Space Sci. Rev., 71, 761-796, 1995.

Grocott, A., Cowley, S. W. H., Sigwarth, J. B., Watermann, J. F., and Yeoman, T. K.: Excitation of twin-vortex flow in the nightside high-latitude ionosphere during an isolated substorm, Ann. Geophysicae, 20, 1577-1601, 2002.

Grocott, A., Cowley, S. W. H., and Sigwarth, J. B.: Ionospheric flows and magnetic disturbance during extended intervals of northward but $\mathrm{B}_{y}$-dominated IMF, Ann. Geophysicae, 21, 509538, 2003.

Grocott, A., Yeoman, T. K., Nakamura, R., Cowley, S. W. H., Frey, H. U., Reme, H., and Klecker, B.: Multi-instrument observations of the ionospheric counterpart of a bursty bulk flow in the nearEarth plasma sheet, Ann. Geophysicae, in press, 2004.

Heppner, J. P. and Maynard, N. C.: Empirical high-latitude electric field models, J. Geophys. Res., 92, 4467-4489, 1987.

Huang, C.-S., Sofko, G. J., Koustov, A. V., MacDougall, J. W., Greenwald, R. A., Ruohoniemi, J. M., Villain, J. P., Lester, M., Watermann, J., Papitashvili, V. O., and Hughes, W. J.: Long-period magnetospheric-ionospheric perturbations during northward interplanetary magnetic field, J. Geophys. Res., 106, 13 091-13 103, 2001.

Jørgensen, T. S., Friis-Christensen, E., and Wilhjelm, J.: Interplanetary magnetic fields and high-latitude ionospheric currents, J. Geophys. Res., 77, 1976-1977, 1972.

Khan, H. and Cowley, S. W. H.: Observations of the response time of high latitude ionospheric convection to variations in the interplanetary magnetic field using EISCAT and IMP-8 data, Ann. Geophysicae, 17, 1306-1335, 1999.

Kirkwood, S., Opgenoorth, H. J., and Murphree, J. S.: Ionospheric conductivities, electric fields and currents associated with auroral substorms measured by the EISCAT radar, Planet. Space Sci., 36, 1359, 1988.

Lockwood, M., Sandholt, P. E., Cowley, S. W. H., and Oguti, T.: Interplanetary field control of dayside auroral activity and the transfer of momentum across the dayside magnetopause, Planet. Space Sci., 37, 1347-1365, 1989.

Lockwood, M., Moen, J., Cowley, S. W. H., Farmer, A. D., Løvhaug, U. P., Lühr, H., and Davda, V. N.: Variability of dayside convection and motions of the cusp/cleft aurora, Geophys. Res. Lett., 20, 1011-1014, 1993.

McComas, D. J., Bame, S. J., Barker, P., Feldman, W. C., Phillips, J. L., Riley, P., and Griffee, J. W.: Solar Wind Electron Proton Alpha Monitor (SWEPAM) for the Advanced Composition Explorer, Space Sci. Rev., 86, 563-612, 1998.

Mende, S. B., Heetderks, H., Frey, H. U., Lampton, M., Geller, S. P., Habraken, S., Renotte, E., Jamar, C., Rochus, P., Spann, J., Fuselier, S. A., Gerard, J.-C., Gladstone, R., Murphree, S., and Cogger, L.: Far ultraviolet imaging from the IMAGE spacecraft. 1. System design, Space Sci. Rev., 91, 243-270, 2000a.

Mende, S. B., Heetderks, H., Frey, H. U., Lampton, M., Geller, S. P., Abiad, R., Segmund, O. H. W., Tremsin, A. S., Span, J., Dougani, H., Fuselier, S. A., Magoncelli, A. L., Bumala, M. B., Murphree, S., and Trondsen, T.: Far ultraviolet imaging from the IMAGE spacecraft. 2. Wideband FUV imaging, Space Sci. Rev.,
91, 271-285, 2000b.

Milan, S. E., Lester, M., Cowley, S. W. H., and Brittnacher, M.: Convection and auroral response to a southward turning of the IMF: Polar UVI, CUTLASS, and IMAGE signatures of transient magnetic flux transfer at the magnetopause, J. Geophys. Res., 105, 15 741-15 755, 2000.

Moen, J., Sandholt, P. E., Lockwood, M., Denig, W. F., Løvhaug, U. P., Lybekk, B., Egeland, A., Opsvik, D., and Friis-Christensen, E.: Events of enhanced convection and related dayside auroral activity, J. Geophys. Res., 100, 23 917-23 934, 1995.

Morelli, J. P., Bunting, R. J., Cowley, S. W. H., Farrugia, C. J., Freeman, M. P., Friis-Christensen, E., Jones, G. O. L., Lester, M., Lewis, R. V., Lühr, H., Orr, D., Pinnock, M., Reeves, G. D., Williams, P. J. S., and Yeoman, T. K.: Radar observations of auroral zone flows during a multiple-onset substorm, Ann. Geophysicae, 13, 1144, 1995.

Nishida, A., Mukai, T., Yamamoto, T., Kokubun, S., and Maezawa, K.: A unifield model of the magnetotail convection in geomagnetically quiet and active times, J. Geophys. Res., 103, 44094418, 1998.

Opgenoorth, H. J. and Pellinen, R. J.: The reaction of the global convection electrojets to the onset and expansion of the substorm current wedge, in "Substorms-4", edited by Kokobun, S. and Kamide, Y., Terra Sci. Publ. Co., Tokyo, 663-668, 1998.

Pinnock, M., Rodger, A. S., Dudeney, J. R., Baker, K. B., Greenwald, R. A., and Greenspan, M.: Observations of an enhanced convection channel in the cusp ionosphere, J. Geophys. Res., 98, 3767-3776, 1993.

Pinnock, M., Rodger, A. S., Dudeney, J. R., Rich, F., and Baker, K. B.: High temporal and spatial observations of the ionospheric cusp, Ann. Geophysicae, 13, 919-925, 1995.

Provan, G., Yeoman, T. K., and Milan, S. E.: CUTLASS Finland radar observations of the ionospheric signatures of flux transfer events and the resulting plasma flows, Ann. Geophysicae, 16, 1411-1422, 1998.

Reiff, P. H. and Burch, J. L.: IMF $\mathrm{B}_{y}$-dependent plasma flow and Birkland currents in the dayside magnetosphere 2. A global model for northward and southward IMF, J. Geophys. Res., 90, 1595-1609, 1985.

Ruohoniemi, J. M. and Greenwald, R. A.: Statistical patterns of high-latitude convection obtained from Goose Bay HF radar observations, J. Geophys. Res., 101, 21 743-21 763, 1996.

Ruohoniemi, J. M. and Baker, K. B.: Large-scale imaging of highlatitude convection with Super Dual Auroral Radar Network HF radar observations, J. Geophys. Res., 103, 20 797-20 811, 1998.

Sandholt, P. E., Farrugia, C. J., Moen, J., and Cowley, S. W. H.: Dayside auroral configurations: responses to southward and northward rotations of the interplanetary magnetic field, J. Geophys. Res., 103, 20 279-20 295, 1998a.

Sandholt, P. E., Farrugia, C. J., Moen, J., Noraberg, Ø., Lybekk, B., Sten, T., and Hansen, T.: A classification of dayside auroral forms and activities as a function of IMF orientation, J. Geophys. Res., 103, 23 325-23 345, 1998 b.

Sandholt, P. E., Farrugia, C. J., Cowley, S. W. H., and Lester, M.: Dayside auroral bifurcation sequence during $\mathrm{B}_{y}$-dominated interplanetary magnetic field: Relationship with the merging and lobe convection cells, J. Geophys. Res., 106, 15 429-15444, 2001.

Senior, C., Cerisier, J.-C., Rich, F., Lester, M., and Parks, G. K.: Strong sunward propagating flow bursts in the night sector during quiet solar wind conditions: SuperDARN and satellite observations, Ann. Geophysicae, 20, 771-786, 2002. 
Smith, C. W., Acuña, M. H., Burlaga, L. F., L'Heureux, J., Ness, N. F., and Scheifele, J.: The ACE Magnetic Field Experiment, Space Sci. Rev., 86, 613-622, 1999.

Stone, E. C., Frandsen, A. M., Mewaldt, R. A., Christian, E. R., Margolies, D., Ormes, J. F., and Snow, F.: The Advanced Composition Explorer, Space Sci. Rev., 86, 1-22, 1998.

Todd, H., Cowley, S. W. H., Lockwood, M., Willis, D. M., and Lühr, H.: Response time of the high-latitude dayside ionosphere to sudden changes in the north-south component of the IMF, Planet. Space Sci., 36, 1415, 1988.

Walker, A. D. M., Pinnock, M., Baker, K. B., Dudeney, J. R., and Rash, J. P. S.: Strong flow bursts in the nightside ionosphere during extremely quiet solar wind conditions, Geophys. Res. Lett., 25, 881-884, 1998.
Walker, A. D. M., Baker, K. B., Pinnock, M., Dudeney, J. R., and Rash, J. P. S.: Radar observations of magnetospheric activity during extremely quiet solar wind conditions, J. Geophys. Res., doi:10.129/2001JA000063, 2002.

Yeoman, T. K. and Lühr, H.: CUTLASS/IMAGE observations of high-latitude convection features during substorms, Ann. Geophysicae, 15, 692-702, 1997.

Yeoman, T. K., Davies, J. A., Wade, N. M., Provan, G., and Milan, S. E.: Combined CUTLASS, EISCAT and ESR observations of ionospheric plasma flows at the onset of an isolated substorm, Ann. Geophysicae, 18, 1073, 2000. 